\title{
The Effect of Financial Technology on Money Demand: Evidence from Selected African States
}

\author{
Submitted 25/01/20, 1st revision 10/02/20, 2nd revision 27/02/20, accepted 04/03/20
}

\section{Courage Mlambo ${ }^{1}$ and Steven Kayambazinthu Msosa ${ }^{2}$}

\begin{abstract}
:
Purpose: The study sought to test the effect of financial technology on money demand in selected African states. The study drew from the fact that there is significant latent demand for digital payments in many markets of sub-Saharan Africa, and widespread consumer acceptance of mobile-communications technology is highly encouraging. The study sought to examine the effect of technology, among other things, on money demand.

Design/Methodology/Approach: The study used panel data and a GMM panel technique to analyse the study's findings.

Findings: Results showed that all variables that captured financial technology have a negative effect with money demand (MD). Both Mobile Subscriptions (MS) and ATM (Automated Teller Machines) have a negative relationship with money demand (MD).

Practical implications: Based on the results obtained in this study, the study recommended that Central Banks need to monitor and predict the consequences of financial innovations. As African states proceed with reforms of its financial sector, the stability of the demand for money would have to be reexamined and instruments of the Central Bank modified to ensure an effective control of money demand.

Originality/Value: A little has been done on the effect of technological developments on money demand in Africa. An understanding of the way technological developments may positively or negatively impact on money demand may guide Central banks in adopting and implementing appropriate monetary policies and actions.
\end{abstract}

Keywords: Money demand, financial innovation, financial technology, money supply, monetary policy.

JEL code: E41, E44.

Paper type: Research article.

\footnotetext{
${ }^{1}$ Post-Doctoral Fellow, corresponding author, Mangosuthu University of Technology, South Africa, mlamboct@gmail.com

${ }^{2}$ Post-Doctoral Fellow. Mangosuthu University of Technology, South Africa.
} 


\section{Introduction}

The demand for money signifies the need by economic agents to hold assets in a form that can be effortlessly exchanged for goods and services. It can also be defined as the demand for financial payments (flow), or as the demand for real cash balances (stock) (Hulsmann, 2009). The demand for money is an important element in the preparation of monetary policy. Literature on the demand for money continues to be an area of investigation (Manamba, 2017) because understanding money demand is important for the comprehension of macroeconomics and monetary policy (Dunne and Kasendeke, 2016; Shafiq and Maliq, 2018; Kumar, Webber and Fargher, and Huber and Marchesiani, 2018). An in-depth comprehension of the strong determinants of the demand for money forms the central in the handling of monetary policy as it facilitates a policy-driven change in monetary policy instruments to have foreseeable influences on growth, price level, and other macroeconomic variables (Manamba, 2017). This shows that the demand for money function is crucial for successful monetary policy design and management in an economy.

According to Edet, Udo, and Etim (2017) studies on the demand for money have increased extensively and is attributed to the following: (i) a stable money demand function contributes to broader economic growth, (ii) knowing the determinants of money demand is important in the drawing up of monetary policy (Halicioglu and Ugur, 2005; Nachega, 2011). Columba (2009) also stated that a thorough assessment of money demand is appropriate to understand the long run relation between money and other macroeconomic variable such as inflation and output. Valadkhani (2006) cited in Ozturk And Ali Acaravci (2008) argue that a well-specified money demand function is still important and it assists in assessing exactly how monetary policy effects upon the economy. Columba (2009) further state that money demand is intensively investigated due to the significance of an exact estimation of its parameters to better inform a number of fundamental economic policy judgments.

Recently, evidence has surfaced from numerous countries to indicate that the traditional money demand connections may have changed and a widespread justification for this has been the continued developments in financial innovation (Dunne and Kasendeke, 2016). The financial sector has experienced technological developments in the last couple of decades, including automated teller machines (ATMs), payment systems, money transfers, automatic bill payer accounts, and credit cards. Bara (2008) argues that a substitution between cash and the different kinds of instruments is taking place. There is a tendency towards a more efficient and less expensive payments system. Fujiki and Tanak (2010) concur and state that because of its easiness, financial technology has been embraced across the globe, principally for fare payment. The overall effect of technology innovations on money demand is an area of some empirical investigation. Empirical studies have incorporated financial technology in the money demand functions due to the growth in financial technology over the last couple of decades. Arrau and De Gregorio, cited in Aliha, Sarmidi and Said (2018) maintain that a money demand specification that does not incorporate financial technology is incorrectly specified and this is commonly referred to as "missing money". It can thus be said that in order to assess monetary policy implementation it is appropriate to identify probable shifts in money demand factors due to financial technology.

Carstens (2019) notes that technological developments have constantly restructured the financial system, either by altering the essence of money or the functioning of the payment system. Continued developments in payment instruments such as credit and debit cards have 
helped to reduce demand for cash in day-to-day dealings. Actually, financial innovation can change the money demand specification (Musango, 2015 and Dunne and Kasendeke, 2016) and lessen the relative amount of cash held, thus positively affecting velocity of money (Abednego and Apriansah, 2010; Shiva and Durai, 2017). Although the influence of financial technology on money demand has been extensively investigated in high income countries, limited studies have investigated this issue in low income countries, which is somewhat surprising given the significant growth in financial technology in some low-income economies (Dunne and Kasendeke, 2016). In light of this this study seeks to examine the effect of financial technology on money demand in selected African states. The study draws from the fact that there is substantial demand for technological payments in many economies of sub-Saharan Africa, and extensive consumer acceptance of mobile-communications technology is highly encouraging (Kendall, Schiff and Smadja, 2014).

\section{Literature Review}

Schoellner (2002) found that credit card usage reduces the demand for real cash balances of households and increases checking and savings accounts balances. Columba (2009) analysed the effect of transaction financial innovation on narrow money in Italy. The study found that transaction financial innovation had a negative effect on the demand for currency in circulation. However, the effect of financial technology on M1 was positive. Zandi and Singh (2010) found that there was a positive relationship between card usage and consumption and output. The magnitude of the relationship was high in high income countries compared to low income countries. Kumar (2011) note that many developing countries have underdeveloped, undiversified financial markets that lack financial sector instruments and payment technologies such that most transactions involve the use of narrow money. Therefore, one should expect that the income elasticity of money demand should be around, or slightly above, unity.

However, studies of African economies have attained implausibly high or implausibly lowincome elasticities. Yang and King (2011) argue credit card banks unlike commercial banks do not create money and therefore cannot affect either the aggregate demand for or the supply of money whereas Holly (1999) observed mixed effects of payment technologies on demand for and supply of money in US. Snellman, Vesala and Humphery cited in Tehranchian (2012) estimated the money demand equation for 10 European countries, by using the panel data for 1987-996. The study found that financial technology created a lowering effect on money demand.

Kipsang (2013) examined the relationship between demand for money and levels of prices, interest rates, real national output, exchange rate and the pace of financial innovation in Kenya using data from 1970 to 2012 using cointegration and error-correction model. It was found that financial innovation process which was measured as the ratio of M2 to M1 had no impact on money demand balances. This raise questions on why financial innovation was calculated as a ratio of M2 to M1 instead of using the amount transacted through mobile money, ATMs, EFTs and other technological payment systems. Kenyoru (2013) analysed the effects of financial innovation on financial deepening in Kenya using time series date covering the period 2007 to 2012. The results showed that financial innovation had insignificant impact on financial deepening. This means that the rise in mobile money transactions as well as in m-banking in Kenya do not significantly influence financial deepening. Carbo-Valverde and Fransisco (2014) observed that ATM transactions and POS 
transactions are negatively related and have a large economic impact of one on another in Spain and currency demand is positively associated with ATM transactions whereas it is negatively related to POS transactions and the negative effect of POS transactions offsets the positive impact of ATM transactions.

Nakamya (2014) investigated the effect of financial innovation in form of new transaction technologies on demand for narrow money (M1) in Uganda. In particular, it assessed the individual effect of automated teller machines (ATMs) and electronic funds transfers (EFTs) on demand for narrow money. It was established that both ATMs and EFTs increased money demand. The income elasticity of money demand was positive and the interest rate and expected inflation had a negative effect. The positive effect of ATMs and EFTs indicated that there are welfare gains from faster transactions involved. Mega (2014) investigated the determinants of money demand function in Ethiopia. Based on the data, an error correction model (ECM) will be applied to estimate the money demand function in Ethiopia. From the study it is found that, money demand is positively related with real GDP and it is negatively related with expected inflation and real effective exchange rate.

Sakshi (2016) empirically analyses India's money demand function during the period 1996 to 2013 using quarterly data. When the money demand function was estimated using dynamic OLS, it is concluded that GDP and short-term interest rate has a positive impact on money demand (M1). Iftekhar, Mamoon, and Hassan (2016) conducted a study to determine money demand function for Pakistan over the period from 1972-2013. The results revealed that real interest rate had a negative effect upon money demand in Pakistan. Dunne and Kasen (2016) investigated the development of financial innovation and its impact on money demand in the Sub-Saharan African region. The study found that financial innovation is a vital determinant of money demand and it has a negative impact on money demand. Kjosevski and Petkovski (2017) used a panel mean group estimator to examine the dynamic relationships in the money demand model. Results showed the exchange rate, industrial production explained most changes in money demand.

Shiva and Durai (2017) examined the questions that whether the usage of credit and debit cards affect currency demand and seigniorage in India by employing Auto Regressive Distributed Lag (ARDL) approach. The study used macroeconomic data and cards usage data from April 2005 to September 2014. The results found that the use of credit cards is negatively associated with currency demand whereas use of debit cards is positively associated with demand for currency in India. Aliha, Sarmidi, Shaari and Said (2017) tested the effect of ATMs on money demand on a world scale. The study used panel data and results showed that the sensitivity of money demand to ATM is low. Aliha, Sarmidi and Said (2018) applied two different estimation methods, namely DOLS and FMOLS to estimate real demand for money in Australia with the inclusion of financial innovations. The results indicate that an increase in TPI (total payment instruments) leads to the increase of money demand. Dou (2018) empirical results show that China's money demand is mainly decided by income, interest rate and expected inflation rate. However, other factors, such as financial innovation, government debt, capital mobility and currency substitution, play a relatively small role, mainly because China's financial and monetary system has been under reform.

Hussaini and Yusuf (2019) did a study in 5 Asean countries to test the determinants of money demand. Results showed that Gdp per capita reported a positive statistical significant relation at $1 \%$ level from Malaysia, Philippines, Singapore, and Thailand, and insignificant 
relationship at Indonesia with money demand. A negative and significant relationship is found in Malaysia, Philippine, and Thailand between inflation and money demand while Indonesia and Singapore present insignificant results. Indonesia, Philippine, and Thailand present positive and statistically significant results at $10 \%$ level between interest rate and money demand, while Malaysia and Singapore have an insignificant relationship between interest rate and money demand. Lastly, the exchange rate is positively, and significant relationship was observed between exchange rate and money demand while Indonesian has a negative and insignificant relationship.

\section{Methodology}

This study made use of secondary data. Information and statistics was sourced from the World Bank. The study used panel quarterly from 1995 to 2014. Data for 23 years are used in this study; firstly, due to the accessibility of the data, and, secondly, in this period, many African countries received high levels of capital flows. The study used only five Africa countries; South Africa, Botswana, Kenya, Mauritius and Nigeria. This countries were chosen because they are in the top five of the African financial markets index (ABSA, 2018). The study had to pick countries that have well developed financial markets and systems. Shiva and Durai (2017) and Dou (2018) showed that such a financial innovation, play a relatively small role, when the financial and monetary system is weak.

Aliha et al. (2017) investigated the effect of financial innovations on demand for money on a world scale. In order to estimate a demand for real balance of money, Aliha et al. (2017) used the amount of currency in circulation, real gross domestic product denoted by GDP, interest rate and the number of automated teller machines. This study adopts Aliha et al. (2017) model with modifications and the model of this study is as follows:

$$
\begin{aligned}
& M D_{i t}=\beta_{0}+\beta_{1} A T M_{i t}+\beta_{2} M B S_{i t}+\beta_{3} I N F_{i t}+\beta_{4} I N T_{i t}+\beta_{5} G D P_{i t}+
\end{aligned}
$$

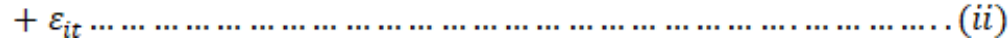

where MD is money demand, ATM is number of automated teller machines, MBS is mobile subscriptions, INF is inflation, INT is interest rates and GDP is gross domestic product.

This technique accounts for unobserved country-specific effects, allows for the inclusion of lagged dependent variables as regressors and controls for endogeneity of all the explanatory variables (Biluess, Mukhtar and Sohail, 2011). Sharma (2018) argues that model estimation using panel GMM estimators gives valid estimates, provided they pass a battery of specifications tests. First, validity of lagged values instrumenting for the differenced variable depends crucially on their being uncorrelated with differenced error term $\left(\varepsilon_{\mathrm{it}}-\varepsilon_{\mathrm{it}-1}\right)$ which can be tested using Sargan test of overidentifying restrictions (Sargan, 1958; Santos, 2015). Second, instrument validity depends upon the assumption of error term being serially uncorrelated (Daumal and Ozyurt, 2010; Sharma, 2018). In order to test for serial correlation, the Arellano and Bond (XXXX) test was used.

\section{Presentation of Results}

Table 1 shows that all variables that captured financial technology have a negative effect with money demand (MD). Both Mobile Subscriptions (MS) and ATM (Automated Teller Machines) have a negative relationship with money demand (MD). Shiva and Durai (2017) if 
the banking system is technically advanced and well developed with greater penetration of bank cards in a country, the amount of currency in circulation will be negatively affected by the debit card usage. Columba (2009) assessed the impact of the diffusion of ATMs (automated teller machines) and of POS (points of sale), on the demand for currency. The study found that transaction technology innovation had a negative effect on the demand for currency in circulation. Snellman, Vesala and Humphery cited in Tehranchian (2012) concluded that the expansion of using electronic payment instruments creates the lowering effect on the demand for money. Dunne and Kasen (2016) and Aliha et al. (2017) indicated that financial innovation is an important determinant of money demand and has a negative effect on it in both the long run and the short run.

Table 1. GMM results

\begin{tabular}{|l|l|l|l|l|}
\hline Variable & Coefficient & Std Error & t-statistic & Prob \\
\hline MBS & -0.3958 & 0.1501 & -2.6359 & 0.0119 \\
\hline INT & 0.3839 & 0.1503 & 2.5537 & 0.0144 \\
\hline INF & 0.4116 & 0.1387 & 2.9663 & 0.0050 \\
\hline GDP & -1.1316 & 0.7370 & -1.5353 & 0.1282 \\
\hline ATM & -0.4496 & 0.0746 & -6.0223 & 0.0000 \\
\hline
\end{tabular}

Results show that interest rates (INT) have a positive relationship with money demand. This is surprising because interest rates are supposed to decrease the demand for money. The results are, however, supported by empirical analusis. Aliha et al. (2017) also found a similar result. Hussaini and Yusuf (2019) present positive and statistically significant results at $10 \%$ level between interest rate and money demand for Indonesia, Philippine, and Thailand. However, the fact that these countries have low income means "people hardly satisfy their basic needs hence limited speculative demand which reduces the influence of interest rate in the demand function for money in these countries" (Bitrus, 2011). Furthermore, Lippi and Scchi (2009) showed that theoretical framework shows how advances in the withdrawal technology shift the money demand curve downwards and reduce its interest elasticity. In other words, interest elasticity of the demand for currency decreases with developments in the withdrawal technology.

Results show that inflation (INF) has a positive relationship with money demand. These results are consistent with empirical literature. Price is an important determinant of the demand for money in the developing countries (Bitrus, 2011). When inflation is high, people will either spend it or invest it before the money loses value. This increases the demand for money. With the unstable prices in developing countries at any point, prices are expected to rise hence panic demand is the order of the day. Dou (2018) also showed that, in China, money demand was influenced by, among other things, inflation. GDP has negative insignificant relationship with money demand. Hussaini and Yusuf (2019) showed that GDP had an insignificant relationship in Indonesia with money demand. This shows that GDP does not influence money demand in the selected African countries.

\section{Conclusion and Recommendations}

The study sought to test the effect of financial technology on money demand in selected African states. The study drew from the fact that there is significant latent demand for digital payments in many markets of sub-Saharan Africa, and widespread consumer acceptance of mobile-communications technology is highly encouraging. The study then sought to examine 
the effect of technology, among other things, on money demand. A good understanding of the stability and robust determinants of the demand for real money balances forms the core in the conduct of monetary policy as it enables a policy-driven change in monetary aggregates to have predictable influences on output, interest rate, and ultimately price through transmission mechanism. Results showed that that all variables that captured financial technology have a negative effect with money demand (MD). Both Mobile Subscriptions (MS) and ATM (Automated Teller Machines) have a negative relationship with money demand (MD). Based on the results obtained in this study, the study recommends that Central Banks need to monitor and predict the consequences of financial innovations. As African states proceed with reforms of its financial sector, the stability of the demand for money would have to be reexamined and instruments of the Central Bank modified to ensure an effective control of money demand. There is, thus, a need for the Central Bank to have a proper understanding of the effects on the instruments of monetary policy of changes in the technology of making and receiving payments. Financial technology advancements should be monitored, and Central Banks should regularly revise policy targeting frameworks and instruments.

\section{References:}

Aliha, M.P., Sarmidi, T., Said, F.F. 2018. Investigating the Effect of Financial Innovations on the Demand for Money in Australia Using Dols and Fmols and Comparing their Predictive Powers. https://ideas.repec.org/a/hrs/journl/vxy2018i1p47-61.html.

Aliha, M.P., Sarmidi, T., Shaari, A.H., Said, F.F. 2017. Payment technologies and money demand at https://ideas.repec.org/a/hrs/journl/vixy2017i1p41-52.html.

Aliha, Sarmidi, Shaari Said 2017. Investigating the Effect of Financial Innovations on Demand For Money On A World Scale: A Systems Gmm Panel Data Approach. http://gbse.com.my/v3no5may17/Paper-89-.pdf

Bara, L. 2008. Money Demand And Adoption Of Financial Technologies: An Analysis With Household Data. ftp://www.cemfi.es/mt/08/T0802.pdf

Barros, C.P., Faria, J.R., and Gil-Alana, L.A. The demand for money in Angola. https://ideas.repec.org/a/spr/jecfin/v41y2017i2d10.1007_s12197-016-9358-6.html.

Berentsen, A., Huber, S., Marchesiani, A. 2018. Limited Commitment and the Demand for Money. The Economic Journal, Vo 128, Issue 610, pages 1128-1156,

Bilquess, F., TMukhtar, T and Sohail, S. 2011. What Matters for Financial Development in D-8 Countries? Capital Flows, Trade Openness and Institutions. Journal of Economic Cooperation and Development, 32, 1 (2011), 71-91

Bitrus , P.Y 2011. The determinants of the demand for money in developed and developing countries. http://www.academicjournals.org/app/webroot/article/article1379761065_Bitrus.pdf

Carstens, A. 2019. General Manager, Bank for International Settlements Central Bank of Ireland, 2019 Whitaker Lecture Dublin, 22 March 2019. https://www.bis.org/speeches/sp190322.htm

Columba, F. 2009. Narrow money and transaction technology: new disaggregated evidence. https://ideas.repec.org/p/pra/mprapa/12689.html

Daumal, M and Ozyurt, S. 2010. The Impact of International Trade Flows on the Growth of Brazilian States. http://www.rei.unipg.it/rei/article/view/27

Dunne, J.P and Kasekende, E. 2016. Financial innovation and money demand in sub-saharan Africa. https://econrsa.org/publications/research-briefs/financial-innovation-andmoney-demand-sub-saharan-africa. 
Edet, N.B., Udo, S.U., and Etim, O.U. 2017. Modelling the Demand for Money Function in Nigeria: Is There Stability? http://rfh.org.pk/jur/wp-content/uploads/2017/03/BBE61-45 57.pdf

Fujiki, H and Tanak, M. 2010. Currency Demand, New Technology and the Adoption of Electronic Money: Evidence Using Individual Household Data. https://www.researchgate.net/publication/228745731_Currency Demand New Tec hnology_and the Adoption_of_Electronic_Money_Evidence_Using_Individual_H ousehold Data

Hulsmann, G.J. 2009. The Demand for Money and the Time-Structure of Production. https://mises.org/library/demand-money-and-time-structure-production

Kendall, J., Schiff, R., and Smadja, E. 2014. Sub-Saharan Africa: A major potential revenue opportunity for digital payments. https://www.mckinsey.com/industries/financialservices/our-insights/sub-saharan-africa-a-major-potential-revenue-opportunity-fordigital-payments

Kumar, S., Webber, D.J and Fargher, S. 2011. Money demand stability: A case study of Nigeria. https://www.sciencedirect.com > science > article > pii

Lippi, F., and Secchi, A. 2009. Technological change and the households' demand for currency. https://ideas.repec.org/p/eie/wpaper/0801.html

Manamba, E. 2017. An Econometric Analysis of Demand for Money and its Stability in Tanzania. http://kspjournals.org/index.php/TER/article/view/1314

Musango, J. 2015. Impact Of Technology Growth On Demand For Currency In Circulation In Kenya.

http://erepository.uonbi.ac.ke/bitstream/handle/11295/90690/Musango_Impact\%20o f\%20Technology\%20Growth\%20on\%20Demand\%20for\%20Currency\%20in\%20Ci rcul.pdf? sequence $=1 \&$ is Allowed $=y$

Nakamya, M. 2014. The effect of financial innovation on money demand in Uganda: An examination of new transaction technologies on demand for narrow money. http://makir.mak.ac.ug/handle/10570/43/browse?value=The+effect+of+financial+in novation+on+money+demand+in+Uganda\%3A+An+examination+of+new+transact ion+technologies+on+demand+for+narrow+money\&type=title

Ozturk, I And Acaravci, A. 2008. The Demand For Money In Transition Economies. Http://Www.Ipe.Ro/Rjef/Rjef2_08/Rjef2_08_2.Pdf

Roodman D. How to do xtabond2: An introduction to difference and system GMM in Stata. Stata Journal. 9(1):86-136.

Santos, A.R. 2015. Financial deepening and economic growth: A System GMM Panel Analysis with application to 7 SSA countries.

Sargan, J.D. 1958. The estimation of economic relationships using instrumental variables. Econometrica: Journal of the Econometric Society. 1958 Jul 1; 26(3):393-415.

Shafiq, H And Malik , W.S. 2018. Money Demand Function Revisited: The Role Of Asset Prices In Pakistan. https://ideas.repec.org/p/pra/mprapa/65789.html

Sharma, R. 2018. Health and economic growth: Evidence from dynamic panel data of 143 years. https://journals.plos.org/plosone/article?id=10.1371/journal.pone. 0204940

Shiva, R.K., Durai, R.K. 2017. Impact Of Credit Cards And Debit Cards On Currency Demand And Seigniorage: Evidence From India. https://www.abacademies.org/articles/impact-of-credit-cards-and-debit-cards-oncurrency-demand-and-seigniorage-evidence-from-india-6753.html.

Tehranchian, A.M., Samimi, A.J and Yazdandoust, A. 2012. The Impact of Modern Technology on Demand for Money in Iran. https://ier.ut.ac.ir/article 32742.html. 